\title{
JEJAK PRAKTIK BEREKONOMI ISLAM DALAM MASYARAKAT MUSLIM INDONESIA DAN MASA DEPANNYA
}

\author{
Nur Kholis \\ Program Studi Ekonomi Islam, FIAI UII, Yogyakarta \\ 014210101@uii.ac.id, http://nurkholis77.staff.uii.ac.id/
}

\section{ABSTRACT}

This article proposes to elaborate and describe the clue of Islamic economic practice in Indonesian moslem society and analyze its future. Some economic activities practiced by Indonesian moslem, after Islam spreadied in Indonesia, identified based on figh muamalah rules that nature rules of Islamic economics. Some of their economics activities done by practicing profit sharing mechanism, avoiding riba/interest, down payment based on bay' al-urbun, bay' al-istisna' etc. Although there are some fact that Islamic economic norms practiced by Indonesian moslem, the government of Indonesia in the era of New Orderand the beginning of reformation era did not support the development of Islamic economic. It effected the practice of Islamic economics in Indonesia was amending slowly. Last ten years, support of Indonesian government to develop Islamic economic practice was significance. It effected the development of Islamic economic practice in many sectors of finance and business is very impressed. It means that the influence of the islamic political economy of Indonesian government to the development of Islamic economic practice in the Indonesian society is very signifinace.

Key words: praktik ekonomi Islam, masyarakat Indonesia, bagi hasil, qardh al-hasan, bai' as-salam, ijarah, bai' alurbun. .

\section{Pendahuluan}

Islam diyakini sebagai agama yang universal, untuk seluruh umat manusia, tidak terbatas oleh ruang dan waktu. Secara eksplisitAl-Quran menyatakan bahwa ajaran Islam berlaku untuk seluruh umat manusia (QS Saba (34): 28 dan QS Al-Anbiya (21): 107). Selain itu ajaran Islam merupakan ajaran yang komprehensif dan sempurna, mengatur secara lengkap seluruh aspek kehidupan, termasuk aturan kehidupan berekonomi (Basyir, 1999). Ketika Islam masuk ke Indonesia, maka aturan kehidupan berekonomi pun juga telah masuk sebagai aturan berekonomi yang mengatur kehidupan umat Islam.

Dalam kriteria ajaran Islam, umat Islam diperintahkan untuk masuk Islam secara kaffah (keseluruhan). Hal ini ditegaskan dalamAl-Quran Surat al-Baqarah: 208 yang artinya: "Hai orang-orang yang beriman, masuklah kamu ke dalam Islam secara keseluruhannya, dan janganlah kamu turutlangkah-langkah syaitan. Sesungguhnya syaitan itu musuh yang nyata bagimu. Kaffah artinya dalam semua syariat Islam, yaitu aqidah, ibadah, muamalah, dan akhlak.

Dengan demikian, ketika Islam masuk di Indonesia, umat Islam pada masa itu tentu juga berhasrat mengamalkan Islam sebagaimana diperintahkan QS al-Baqarah: 208 tersebut. Isiam sudah berabad-abad masuk ke Indonesia, berarti telah ada jejak praktik bermuamalah yang merupakan aktivitas ekonomi berbasiskan Islam di Indonesia, jauh sebelum secara formal ekonomi Islam memasuki sejarah baru di era modern, sebagaimana dikemukakan KhursidAkhmad yang bermula pada tahun 1930-an..

Islam beserta ajarannya masuk ke Indonesia dengan cara penetrasi, dengan cara yang sangat laten dan membaur dengan berbagai tradisi yang telah ada dan eksis (Muhaimin, 1992). Dengan kata lain Islam masuk ke 
Indonesia tanpa menimbulkan hentakan shoc culture, apalagi memicu kontroversi, sesuatu yang tidak lazim bila dibandingkan dengan sejarah munculnya beberapa ideologi besar di dunia.

Oleh karena itulah, wajah Islam di Indonesia merupakan hasil dialog dan dialektika antara Islam dan budaya lokal yang kemudian menampilkan wajah Islam yang khas Indonesia yang dikenal Islam nusantara. Dalam kenyataannya, Islam di Indonesia memanglah tidak bersifat tunggal, tidak monolit, dan tidak simpel. Islam Indonesia bergelut dengan kenyataan negara-bangsa, modernitas, globalisasi, kebudayaan lokal, dan semua wacana kontemporer yang menghampiri perkembangan zaman dewasa ini. Tulisan ini secara spesifik dimaksudkan untuk menelusuri jejak praktik ekonomi Islam dalam masyarakat muslim Indonesia sebagai wujud dari bagian tampilnya wajah Islam yang khas Indonesia dạn bagaimana masa depannya di Indonesia.

\section{Karakteristik Dasar Islam}

Islam diyakini sebagai.agama yang universal, untuk seluruh umat manusia, tidak terbatas oleh ruang dan waktu. Al-Quran sendiri menyatakan bahwa ajaran Islam berlaku untuk seluruh umat manusia (QS Saba (34): 28 dan QS Al-Anbiya (21): 107). Oleh karena itu, Islam seharusnya dapat diterima oleh setiap manusia, tanpa harus ada pertentangan dengan situasi dan kondisi di mana manusia itu berada. Islam dapat berhadapan dengan masyarakat modern, sebagaimana ia dapat berhadapan dengan masyarakat tradisional. Islam senantiasa cocok untukumat manusia kapanpun dan dimanapun.

Kesiapan Islam menghadapi tantangan zaman selalu dipertanyakan oleh para pemikir muslim kontemporer (Nasution, 1985). Pada dasarnya, ajaran Islam dapat dibedakan menjadi dua kelompok ajaran, qath'iyyat dan dhanniyyat. Pertama, ajaran Islam yang bersifat absolut, universal dan permanen, tidak berubah dan tidak dapat diubah. Termasuk kelompok ini adalah ajaran Islam yang tercantum dalam Al-Qur'an dan hadis mutawatir yang penunjukannya telah jelas ( $q a t^{\prime} i$ al-dalalah). Kedua ajaran Islam yang bersifat relatif, tidak universal dan tidak permanen, dapat berubah dan diubah yang berakar pada nas yang dhanniyat yang membuka ruang berijtihad (Nasution, 1988). Ranah ini memberikan kemungkinan epistemologis hukum bahwa setiap wilayah yang dihuni umat Islam dapat menerapkan hukum Islam secara berbeda-beda karena faktor sejarah, sosiologis, situasi dan kondisi yang berbeda yang melingkupi para mujtahid. Inilah yang disebut figh (fikih). Fiqh dalam penarapan dan aplikasinya justru harus mengikuti kondisi dan situasi sesuai dengan tuntutan kemaslahatan dan kemajuan zaman. Hal ini dimaksudkan agar prinsip maslahat tetap terpenuhi dan terjamin. Sebab fiqh adalah produk zamannya. Fiqh yang pada saat diijtihadkan oleh mujtahid dipandang tepat dan relevan, mungkin kini dipandang menjadi kurang atau bahkan tidak relevan lagi (PP IKAHA, 1996). Dalam suatu kaidah (al-Qayyim, 1977) diungkapkan:

$$
\text { تغير المفتوى واختلافهابحسب تنغير الازمنة والامكنة والاحوال والنيات والعواند }
$$

Artinya: "Fatwa hukum Islam dapat berubah sebab berubahnya masa, tempat, situasi, dorongan, dan motivasi".

Ajaran Islam yang termasuk kelompok yang bersifat relatif (zanniyat), ternyata lebih banyak jumlahnya jika dibandingkan dengan ajaran Islam yang bersifat absolut dan permanen, terlebih lagi untuk wilayah muamalah dalam bidang ekonomi. Dalam wilayah muamalah ini terdapat kaidah fighiyah yang sangat relevan yaitu:

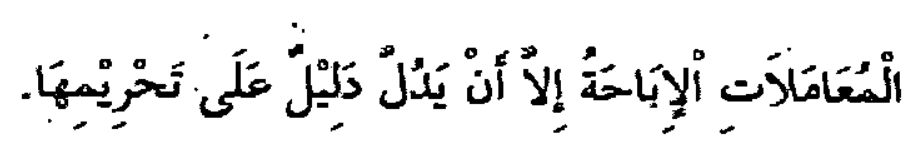

Artinya: Pada dasarnya, semua bentuk muamalah boleh dilakukan kecuali ada dalil yang mengharamkannya

Kaidah ini berdasar firman Allah yang artinya, "Allah sungguh telah memerinci apa saja yang diharamkan untuk kamu sekalian". (Terjemahan Surah al-An'am (6): 119). Ini-maknanya bahwa segala sesuatu yang haram telah diperincikan secara detail dalam syarak, sedangkan yang mubah (dibolehkan) tidaklah diperinci secara 


\section{UNISIA, VOL. XXXIII No. 74 JANUARI 2011}

detail dan tidak pula dibatasi secara detail, sehingga para ulama berkesimpulan bahwa hukum asal muamalat adalah mubah, kecuali ada dalil yang melarangnya. Dengan menerapkan kaedah ini, terbuka luas peluang untuk melakukan adopsi terhadap transaksi-transaksi (muamalah) modem pada era global, selama tidak bertentangan dengan prinsip-prinsip syara' (al-Nadwi, 1999; al-Misri, 1999), seperti terpenuhinya syarat dan rukun kontrak, adanya unsur suka sama suka (al-taradi) dan tidak ada paksaan dari pihak manapun.

Ajaran Islam yang berakar pada nas zanni inilah yang merupakan wilayah ijthadi, yang produknya disebut fiqh. Hukum Islam dalam pengertian inilah yang memberikan kemungkinan epistemologis hukum bahwa setiap wilayah yang dihuni umat Islam dapat menerapkan hukum secara berbeda-beda dengan wajah Islam yang berbeda-beda pula. Hal ini tercermin pada kecenderungan-kecenderungan sistem hukum di negara-negara muslim dewasa ini. Hal ini bukan hanya disebabkan oleh perbedaan sistem politik yang dianut, melainkan juga oleh faktor sejarah, sosiologis dan kultur masing-masing negara muslim tersebut (Ahmad, 1996). Di sinilah Islam berdialog dan berdialektika dengan' kultur lokal sehingga melahirkan Islam yang lebih khas nuansa dan muatan lokalnya.

ljthad sebagai sarana untuk berdialog dan berdialektika antara Islam dan situasi dan kondisi lokalitas dipahami sebagai metode untuk menyelesaikan persoalan-persoalan hukum, baik yang ada nasnya maupun yang tidak terdapat nasnya (Djamil, 1995). litihad dalam Islam sebagaimana dikatakan oleh lqbal merupakan the principle of movement-daya gerak kemajuan umat Islam (lqbal, 1981). Dengan kata lain, ijthad merupakan kunci dinamika ajaran Islam yang menjadikan Islam salihun li kulli zaman wa li kulli makan (selalu cocok kapan pun dan dimanapun).

Dalam konteks ijthad tersebut, perlu ditegaskan bahwa tujuan utama penetapan hukum Isiam adalah untuk mewujudkan kemaslahatan umat manusia, baik di dunia maupun di akhirat. Hal ini sejalan dengan misi . Islam secara keseluruhan yang rahmatan Iil'alamin. Bahkan asy-Syatibi (tt: juz II) dalam al-Muqafaqat menegaskan:

$$
\text { ومطوم ان الثريعة انما وضعت لمصالح الظقى باطلاق }
$$

Artinya: "Telah diketahui bahwa hükum Islam itu disyariatkan/diundangkan untuk mewujudkan kemaslahatan makhluk secara mutlak".

Ungkapan tersebut menggambarkan secara jelas bagaimana eratnya hubungan antara hukum Islam dengan kemaslahatan. Mengenai-pemaknaan terhadap maslahat, para ulama mengungkapkannya dengan definisi yang berbeda-beda. Menurut al-Khawarizmi, maslahat merupakan pemeliharaan terhadap tujuan hukum Islam dengan menolak bencana/kerusakan/hal-hal yang merugikan dari makhluk (manusia) (Al-Syaukani, tt: 242). Sementara menurut at-Tufi, maslahat secara urf merupakan sebab yang membawa kepada kemaslahatan (manfaat), sedangkan dalam hukum Islam, maslahat merupakan sebab yang membawa akibat bagi tercapainya tujuan Syari' (Allah), baik dalam bentuk ibadat maupun mu'amalat (Yusdani, 2000). Sedangkan menurut alGhazali, maslahat makna asalnya merupakan menarik manfaat atau menolak mudarat. Akan tetapi yang dimaksud maslahat dalam hukum Islam adalah setiap hal yang dimaksudkan untuk memelihara agama, jiwa, akal, keturunan, dan harta. Setiap hukum yang mengandung tujuan memelihara kelima hal tersebut disebut - maslahat (Al-Ghazali, tt: 286-287).

Al-Ghazali menyatakan bahwa setiap maslahat yang bertentangan dengan al-Qur'an, sunah, atau ijma' adalah batal dan harus dibuang jauh-jauh. Setiap kemaslahatan yang sejalan dengan tindakan syara' harus diterima untuk dijadikan pertimbangan dalam penẹtapan hukum Islam. Dengan pernyataan ini, al-Ghazali ingin menegaskan bahwa tak satu pun hukum Islam yang kontra dengan kemaslahatan, atau dengan kata lain tak akan ditemukan hukum Islam yang menyengsarakan dan membuat mudarat umat manusia. 
Kemaslahatan yang ingin diwujudkan hukum Islam bersifat universal, kemaslahatan sejati, bersifat duniawi dan ukhrawi, lahir dan batin, material dan spiritual, maslahat individu dan maslahat umum, maslahat hari ini dan esok. Semua terlindungi dan terlayani dengan baik, tanpa membedakan jenis dan golongan, status sosial, daerah dan asal keturunan, orang lemah atau kuat, penguasa atau rakyat jelata (Qardawi, tt: 62). Dengan demikian, peranan maslahat dalam hukum Islam sangat dominan dan menentukan, karena tujuan pokok hukum Islam adalah untuk mewujudkan kemaslahatan sebagaimana yang telah disebutkan.

\section{Bagi Hasil Sebagai Aktivitas Ekonomi yang Dianjurkan Islam}

\section{1). Konsep Bagi Hasil}

Bagi hasil merupakan istilah yang sangat populer di Indonesia. Secara definitif, aktivitas bagi hasil adalah sebuah usaha yang dibangun berdasarkan kesepakatan antara pemodal dan pengusaha untuk memberikan pembagian hasil berdasarkan. persentase tertentu dari hasil usaha. Kesepakatan itu dilakukan secara adil dan transparan. Adil artinya setiap mitra mendapatkan bagi hasil sesuai dengan kontribusi yang diberikannya, baik modal, keterampilan maupun tenaga, sementara transparan diartikan bahwa pemodal dan pengusaha saling mengetahui jumlah bagi.hasil yang diperolehnya dan progres usaha itu sendiri (Jusmaliani, 2006).

Sedangkan menurut pengertian lain, bagi hasil adalah sebuah kerja sama antara pemilik modal dan pengusaha untuk saling berbagi keuntungan ataupun kerugian sehingga dengan adanya kerja sama ekonomi, akan terbangun pemerataan dan kebersamaan (Muhammad, 2002). Dalam realitasnya aktivitas bagi hasil banyak dipraktikkan masyarakat. Dalam hal ini terdapat argumentasi logis yang mendasarinya yaitu bahwa risiko yang ditanggung masing-masing pihak akan lebih sedikit karena ditanggung bersama dan pengelolaan usaha akan lebih transparan. Di samping itu system bagi hasil akan menghilangkan keberpihakan kepada pemodal, sekaligus membuka peluang yang sama antara pemodal dan pengusaha. Oleh karena itu, dalam ekonomi Islam, setiap transaksi yang dilakukan harus berpegang kepada keadilan, kejujuran, transparansi, dan menghindari riba (Karomah, 2010).

Secara konseptual, sistem bagi hasil memposisikan pemodal tidak hanya bertindak sebagai pemberi pinjaman dana, melainkan sebagai investor yang akan menyumbangkan dana finansial untuk tujuan-tujuan produktif. Di lain pihak; pengusaha sebagai pengelola dana akan bertindak sebagai enterpreneur. Hubungan antara kedua belah pihak àdalah kemitraan dan kerja sama, bukan layaknya hubungan yang terjadi dalam transaksi pinjam meminjam (Karomah, 2010), terlebih lagi pinjam meminjam yang berbasis membungakan uang.

Ada dua perbedaan mendasar antara investasi dengan membungakan uang. Perbedaan tersebut dapat ditelaah dari definisi hingga makna masing-masing. Investasi adalah kegiatan usaha yang mengandung risiko karena berhadapan dengan unsur ketidakpastian. Dengan demikian, perolehan kembaliannya (return) tidak pasti dan tidak tetap. Sedangkan membungakan uang adalah kegiatan usaha yang kurang mengandung risiko karena perolehan kembaliannya berupa bunga yang relatif pasti dan tetap (Antonio, 2001).

\section{2). Islam dan Bagi Hasil}

Islam mendorong masyarakat ke arah usaha nyata dan produktif. Islam mendorong seluruh masyarakat untuk melakukan investasi dan melarang membungakan uang. Investasi dapat dilakukan dengan metode bagi hasil (reward sharing). Sistem ini merupakan alternatif praktik bunga yang ribawi. Perolehản nisbah bagi hasil dilakukan melalui proses kerjasama usaha antara dua atau lebih mitra kerja (Karomah, 2010).

Menyimpan uang di bank Islam termasuk kategori kegiatan investasi karena perolehan kembaliannya (return) dari waktu ke waktu tidak pasti dan tidak tetap. Besar kecilnya perolehan kembali itu tergantung kepada 
hasil usaha yang benar-benar terjadi dan dilakukan bank sebagai mudharib atau pengelola dana. Dengan demikian; bank Islam tidak dapat sekadar menyalurkan uang. Bank Islam harus terus berupaya meningkatkan kembalian atau return of investment sehingga lebih menarik dan lebih memberi kepercayaan bagi pemilik dana.

Islam mendorong praktek bagi hasil serta mengharamkan riba. Keduanya sama-sama memberi keuntungan bagi pemilik dana, namun keduanya mempunyai perbedaan yang sangat nyata. Perbedaan itu dapat dijelaskan dalam tabel berikut.

\section{Perbedaan Bunga dan Bagi Hasil}

\begin{tabular}{|l|l|}
\hline \multicolumn{1}{|c|}{ Bunga } & \multicolumn{1}{c|}{ Bagi Hasil } \\
\hline $\begin{array}{l}\text { Penentuan bunga dibuat pada waktu akad } \\
\text { dengan asumsi harus selalu untung }\end{array}$ & $\begin{array}{l}\text { Penentuan besarnya rasio/ nisbah bagi hasil } \\
\text { dibuat pada waktu akad dengan } \\
\text { berpedoman pada kemungkinan untung rugi }\end{array}$ \\
\hline $\begin{array}{l}\text { Besarnya persentase berdasarkan pada } \\
\text { jumlahuang (modal) yang dipinjamkan. }\end{array}$ & $\begin{array}{l}\text { Besarnya rasio bagi hasil berdasarkan pada } \\
\text { jumlah keuntungan yang diperoleh }\end{array}$ \\
\hline $\begin{array}{l}\text { Pembayaran bunga tetap seperti .yang } \\
\text { dijanjikan tanpa pertimbangan apakah } \\
\text { proyek yang dijalankan oleh pihak nasabah } \\
\text { untung atau rugi. }\end{array}$ & $\begin{array}{l}\text { Bagi hasil tergantung pada keuntungan } \\
\text { proyek yang dijalankan. Bila usaha merugi, } \\
\text { kerugian akan ditanggung bersama oleh } \\
\text { keduabelah pihak. }\end{array}$ \\
\hline $\begin{array}{l}\text { Jumlah pembayaran bunga tidak meningkat } \\
\text { sekalipun jumlah keuntungan berlipat atau } \\
\text { keadaan ekonomi sedang "booming". }\end{array}$ & $\begin{array}{l}\text { Jumlah pembagian laba meningkat } \\
\text { sesuai dengan peningkatan jumlah } \\
\text { pendapatan. }\end{array}$ \\
\hline $\begin{array}{l}\text { Eksistensi bunga diragukan (kalau tidak } \\
\text { dikecam) oleh semua agama termasuk } \\
\text { Islam. }\end{array}$ & $\begin{array}{l}\text { Tidak ada yang meragukan keabsahan bagi } \\
\text { hasil }\end{array}$ \\
\hline
\end{tabular}

Sumber: Syafi'i Antonio, 2001

\section{JejakAktivitas Ekonomi Berbasiskan Ekonomi Islam dalam Masyarakat Indonesia}

Islam datang ke nusantara, di antaranya dibawa oleh para saudagar. Islam masuk ke Indonesia lewat jalur perdagangan international (international trade) dalam suasana yang damai dan tidak bergejolak. Pendekatan lewat perniagaan dan kedamaian yang dipergunakan oleh para da'i, yang nota benenya adalah para pedagang dan saudagar itu sendiri ternyata sangat cocok dengan kondisi sosio-kultural pada saat itu. Karena itulah, Islam dapat diterima oleh masyarakat nusantara dan berkembang dengan cepat di hampir seluruh pesisir utama di Nusantara.

Sementara itu seiring dengan perkembangan Islam di nusantara muncullah kerajaan-kerajaan Islam yang berbasis maritim dan perdagangan internasional. Hubungan dagang dengan dunia luar terutama dengan kerajaan-kerajaan Islam sangat kuat yang dilandasi bukan saja oleh semangat perniagaan melainkan juga oleh ruh ukhuwah /slamiyyah. Hal ini dibuktikan dengan ekspedisi Pangeran Sabrang Lor dari Kesultanan Demak yang 
membantu kekuatan militer Kesultanan Malaka dari serbuan Portugis dan bantuan-bantuan senjata dari kekhilafahan Islam di Turki terhadap kerajaanAceh dalam melawan penjajah Belanda pada abad ke-19.

Sayang sekali bahwa masuknya Islam ke Indonesia ini bersamaan, di.satu pihak, dengan melemahnya kekuatan-kekuatan dunia Islam di hampir seluruh bidang kehidupan dan bangkitnya kembali. dunia Barat dengan energi dan semangat baru (renaissance) di pihak yang lain. Akibatnya perkembangan Islam di Indonesia yang masih sangat baru ini tidak dapat tumbuh dengan sehat dan kuat.

Dalam keadaan demikian datangnya penjajah Barat dengan kekuatan dan semangat baru yang bergelora untuk menguasai daerah-daerah yang menghasilkan rempah dan emas. Tamu yang tidak diundang dan bertampang sangar ini memang sengaja datang untuk menguasai kekayaan tuan rumah yang ramah dan lemah lembut itu. Dengan segala cara dan siasat yang penuh dengan kelicikan akhirnya kerajaan Islam di Indonesia dapat dikuasai satu persatu oleh penjajah Barat Belanda yang juga membawa misi Kristen.

Dalam kurun tiga ratus lima puluh tahun lebih pertumbuhan Islam yang masih bayi di Nusanatara ini mengalami stagnasi, kemandegan bahkan juga keterbelakangan dị hampir seluruh bidang kehidupan duniawi. Keadaan demikian itu ternyata bukan monopoli dari kondisi umat Islam di Indonesia saja, melainkan juga di seluruh persada dunia:Islam.

Dalam kurun yang begitu panjang umat Islam di Nusantara tidak memiliki banyak peluang untuk maju. Mereka hanya memiliki satu pilihan yaitu berjihad melawan penjajah Belanda dengan kekuatan seadanya. Mereka tidak saja ketinggalan dalam bidang perdagangan dan ekonomi dengan bangsa-bangsa lain, bahkan mereka sendiri tidak mampu memberikan bimbingan, pengajaran dan pendidikan kepada generasi muda dengan ajaran-ajaran Islam yang benar. Akibatnya generasi Islam yang tumbuh itu tidak mengenal Islam secara kafah, secara komprehensif dan integral. Mereka memahami. Islam secara parsial dan pemahaman demikian didukung oleh kebijakan politik penjajah Belanda. Gambaran Islam yang benar tidak pernah tampil dalam panggung kehidupan. Yang muncul hanyalah Islam yang compang camping dan lusuh sehingga tidak lagi menarik bahkan bagi kaum Muslimin itu sendiri.

Memang kemudian terjadi beberapa kali perlawanan oleh raja-raja Muslim terhadap kekuasaan penjajah Balanda tersebut dari semenjak awal mereka menginjakkan kakinya di ibu pertiwi. Tetapi perlawanan-perlawanan mereka itu dapat dengan mudah dipatahkan oleh Belanda. Perlawanan-perlawanan yang muncul itu tidak dibangun di atas dasar konsep terpadu dari sistem kehidupan Islam yang berbasis ukhuwah islamiyyah sehingga ketika perlawanan itu sudah dipatahkan oleh penjajah, maka bidang-bidang kehidupan seperti ekonomi, sosial, budaya dan lain-lain akan terimbas dan terpengaruh.

Barulah pada awal abad ke dua puluh perjuangan kaum Muslimin di Indonesia memiliki kerangka pemikiran yang realistis. Dengan berdirinya Syarikat Islam pada tahun 1906 oleh H. Oemar Said Tjokroaminoto dan $H$. Samanhudi di Solo perekonomian ụmat Islam mulai diperhatikan terutama dalam kaitannya untuk memberdayakan potensi umat yang sangat terbelakang itu. Dalam dunia perdagangan banyak sekali tokoh İslam di awal abad dua puluh yang terjun ke dalam dunia bisnis dan menjadi pedagang besar. Persyarikatan Muhammadiyah misalnya, dapat dengan cepat berkembang karena didukung secara material oleh para anggotanya yang banyyak dari kalangan pedagang, terutama pedagang batik. Bahkan pada waktu itu Persyarikatan Muhammadiyah menjadi identik dengan kelas menengah Islam yang tumbuh dari dunia perdagangan. Hal yang sama juga beriaku bagi Ormas-ormas Islam modern lainnya seperti al-Irsyad, Persatuan Islam (Persis), al-Khoirot dan lain-lain.

Kebangkitan ekonomi umat Islam di Indonesia di awal abad dua puluh ini kebetulan bersamaan dengan " kebangkitan umat Islam secara global. Ada sedikit perbedaan wacana antara perkembangan pemikiran ekonomi Islam di Indonesia dengan yang terjadi di berbagai belahan dunia Islam lainnya terutama di Timur Tengah. Lebih 
dari separuh pertama abad dua puluh ini para ulama dan tokoh masyarakat Islam di Indonesia lebih memikirkan bagaimana nasiḅ ekonomi umat Islam yang dari dulu tidak pernah dibenahi dan selalu dipinggirkan oleh penjajah Belanda. Kerana itu mereka agaknya kurang waktu untuk memikirkan dan menggali sistem ekonomi Islam tersendiri yang ruhnya diambil dari al-Qur'an dan as-Sunnah secara komprehensif.

Kita memahami sepenuhnya karena kondisi dan arena di mana mereka hidup di dalamnya tidak mengizinkan mereka untuk berbuat banyak selain dari pada memusatkan perhatian bagaimana mencapai Indonesia merdeka. Akan tetapi itu bukan berarti bahwa umat Islam saat itu tidak mempraktikkan kehidupan ekonomi dengan berasas Islam. Ada beberapa ragam aktivitas ekonomi umat Islam di nusantara (Indonesia) yang - merupakan bentuk kearifan lokal berwajah "Islam nusantara" dalam rangka menampilkan karakter Islam yang salihun likulli zaman wa li kulli makan. Di antara aktivitas ekonomi umat Islam di nusantara (Indonesia) itu antara lain:

\section{1). Penolakan Terhadap Riba (bunga)}

Hal ini selain ditegaskan oleh beberapa kitab yang dikarang oleh ulama tersohor nusantara seperti Syekh Abdur Rauf al-Sinkili dalam karyanya yang bertajuk Wasiyah dan Mir'at al-Tullab, juga Syekh Nuruddin alRaniri dalam kitabnya, al-Fawaid al-Bahiyah, juga dalam bentuk kanun yang diberlakukan pada suatu negeri.

Ini merupakan bagian dari upaya islamisasi dalam kegiatan perniagaan, di mana Islam secara tegas memerangi unsur-unsur penindasan yang bersumber dari meluasnya praktik riba dalam urusan pinjam meminjam. Riba secara bahasa bermakna al-fadl wa al-ziyadah (Anis, tt: 326) (lebihan dan tambahan) atau alidafah (al-Jammal, 1986: 381) (lebihan) kepada sesuatu, al-numuw (al-Maududi, 1987: 94) (tumbuh dan membesar). Sedangkan menurut istilah, riba berarti pengambilan tambahan dari harta pokok atau modal secara batil. Ada beberapa pendapat mengenai definisi riba dari kalangan ulama tafsir. Sebutlah misalnya dari kalangan ulama ahli tafsir seperti Al-Imam Abu Bakr Ahmad Bin 'Ali al-Razi al-Jasas (juz 2, tt) dan 'Imad al-Din bin Muhammad al-Tabari (1985) maupun ulama fikih seperti 'Abdullah IbnAhmad al-Maqdisi Ibn Qudamah (1972) dan Ibn'Abidin (1966).

Sekalipun demikian, secara umum terdapat benang merah yang menegaskan bahwa riba adalah pengambilan tambahan, baik dalam transaksi jual-beli maupun pinjam-meminjam secara batil atau bertentangan dengan prinsip muamalat dalam Islam (al-Qaradawi, 1999). Secara ringkasnya, unsur-unsur riba adalah sebagai berikut: (a) Adanya tambahan/lebihan dari jumlah pokok pinjaman (b) Penentuan tambahan/lebihan itu berkaitan dengan unsur pertimbangan jangka waktu (c) Tawar menawar atau persetujuan terhadap syarat tambahan/lebihan itu ditentukan terlebih dahulu yaitu ketika kontrak pinjaman dilakukan (al-Misri, 1987).

Dalam muamalah (transaksi), riba biasanya mempunyai tiga bentuk (Ghani, 1999) yaitu:

a. Bayaran balik yang melebihi dari jumlah uang pokok (harta asal) yang dipersyaratkan terlebih dahulu ketika kontrak dilakukan.

b. Kontrak ke atas pertukaran barang tertentu yang tidak diketahui dengan pasti persamaannya pada timbangan atau takaran yang diakui oleh syarak.

c. Penangguhan penyerahan salah satu barang yang ditukarkan atau yang diperdagangkan (khususnya untuk pertukaran mata uang dan barang ribawi).

Dalam bahasa Inggris, bunga yang merupakan padanan dari riba dalam bahasa Indonesia sering disebut dengan usury atau interest (Saleh, 1986). Sebagian pakar ekonomi membedakan antara usury dan interest. Jika tingkat bunga itu (dianggap) biasa saja dan wajar maka disebut interest, sedangkan jika tingkat bunga itu terlampau tinggi atau melebihi batas yang dibolehkan undang-undang disebut usury. Dalam bahasa 
Belanda, bunga disebut rente, .oleh karena itu orang yang membungakan uang di masyarakat sering disebut rentenir.

Ada sebagian pemikir muslim yang memandang ada perbedaan antara usury dan interest (Saeed, 1996). Bagi mereka usury adalah adalah bunga yang dibayarkan terhadap pinjaman untuk kegiatan konsumsi (bukan produksi), sebagaimana yang terjadi pada pra Islam. Ini yang menurut mereka adalah riba. Mereka menyamakan usury dengan riba. Sedangkan interestadalah pinjaman untuk kegiatan produksi, menurut mereka, interest dibolehkan dan tidak bertentangan dengan al-Quran, karena larangan dalam al-Quran mengacu. pada larangan riba. Padahal sebutan usury atau interest untuk nama riba itu, pada hakikatnya jenisnya adalah sama saja, hanya beda tingkat saja. Menyebut riba dengan nama bunga, intersest, usury, dan rente tidak akan mengubah sifatnya, karena hakikatnya sama saja. Semuanya dilarang oleh Isiam. Bunga atas pinjaman yang digunakan untuk konsumsi atau produksi sama saja disebut riba karena sama-sama menzalimi pihak yang meminjam (Mannan, 1986; Qureshi, 1961).

Di masyarakat Jawa, pelaku riba disebut dengan lintah darat. Lintah merupakan satu binatang di sawah yang sangat ganas dan bisa membunuh secara perlahan dengan racunnya. Ini merupakan analogi kebencian terhadap para pelaku riba ini. Masyarakat umum memang sangat membenci para pelaku riba ini, yang nampak luarnya menolong tapi sebenarnya menindas dan mencekik leher. Kehadiran para pelaku riba ini sangat mereka benci akan tetapi mereka tak kuasa berbuat banyak, karena para pelaku riba ini mempunyai uang banyak dan selalu dikelilingi para bodyguard. Oleh karena itu, kebencian itu mereka wujudkan dalam bentuk tidak mau bertransaksi dengan mereka. Namun kadang-kadang mereka terpaksa bertransaksi dengan lintah darat tersebut karena kondisi yang memaksa, terutama karena tidak tersedianya lembaga keuangan yang dapat mereka akses.

Pada masa kesultanan Malaka, kegiatan mempraktikkan riba ini dilakukan oleh saudagar Tamil Hindu, disebut sebagai Cheti. Para Cheti ini merupakan golongan lintah darat yang memeras keuntungan yang berlipat ganda dengan basis bunga yang dikenakan ke atas pinjaman. Mereka sudah lama berselisih päham dengan para saudagar muslim dari Gujarat. Pada saat genting, para Chetitersebut berkhianat terhadap Sultan. Melaka dengan menyokong Portugis.

Para saudagar dari Gujarat yang muslim bersahabat rapat dengan para muslim Melayu. Persahabatan inilah yang mengokohkan mereka untuk menolak praktik riba darì para Cheti. Para muslim Melayu sangat benci terhadap amalan riba karena selain para pelaku riba itu berkhianat, juga kebanyakan yang menjadi mangsa operasi riba ini adalah orang Melayu (Abdullah, 2001).

Dengan demikian dapat dikatakan bahwa penolakan terhadap riba sudah berlangsung sejak lama dan telah menjadi bagian dari aktivitas ekonomi yang dihindari oleh umat Islam. Hal itu disebabkan karena selain faktor ajaran agama Islam yang mengharamkannya, juga karena faktor situasi dan kondisi lokal nusantara yang menjadikan mereka membenci praktek riba yang menindas.

\section{2). Praktik Bagi Hasil yang berasaskan Syirkaih.}

Praktik bagi hasil di masyarakat sangat beragam. Pada sektor pertanian di Jawa dikenal pola bagi hasil dengan tenaga kerja saat panen yang dikenal dengan istilah bawon. Di samping itu ada juga istilah maro/paro, mrotelu, dan lain-lain. Pada sektor peternakan dikenal istilah gaduh yang variasinya ada yang disebut babon, doro, maro bathi. Pada sektor perikanan ada istilah garap dan marnen (Karomah, 2010).

Pada saat sekarang, pola bagi hasil bahkan sudah merambah ke sektor bisnis yang berskala besar. Misalnya pola bagi hasil yang diterapkan restoran padang "Sederhana". Restoran ini sudah berjumlah sekitar 100 unit. Dari jumlah tersebut yang benar-benar dimiliki sendiri oleh pemiliknya hanya 10 buah, selebihnya dilakukan melalui kerjasama dengan investor melalui sistem bagi hasil. 
- Pola bagi hasil juga diterapkan dalam bisnis yang perpola franchise (waralaba) baik untuk produk makanan seperti restoran, makanan siap saji, makanan ringan (es krim, yoghurt, baked goods, donat, pastry, dan lain-lain. Dalam franchise tersebut digunakan beberapa sistem, yaitu sistem business format, waralaba bagi keuntungan, waralaba kerjasama investasi, dan waralaba merek dagang. Semuanya berprinsip kepada prinsip bagihasil.

Pada masyarakat Melayu di kepulauan Sumatera zaman dufu, praktik bagi hasil dalam investasi disebut sebagai commenda. Praktik ini merupakan bentuk kerjasama yang dilakukan dengan cara menyerahkan barang dagangan kepada orang lain (saudagar, pedagang dan pengusaha) untuk diperdagangkan ataupun memberikan uang sebagai modal untuk menggerakkan suatu bisnis. Kegiatan yang demikian ini dilakukan oleh para raja dan pembesar negeri dengan menyediakan barang ataupun modal kepada saudagar. Perniagaan ini dilkat dengan perjanjian pembagian keuntungan menurut ketentuan setempat(Notosusanto, 1984).

Jenis perniagaan commenda ini banyak berlaku di dalam sejarah kesultanan Melayu. Ini terjadi karena timbulnya kecenderungan dari pihak istana melibatkan diri dalam perniagaan dan perdagängan. Pada zaman Kesultanan Aceh, Sultan Iskandar Muda terkenal sebagai seorang saudagar besar karena keterlibatannya dalam perdagangan.

\section{3). Pinjaman Tànpa Bunga (Qard al-Hasan)}

Pinjam meminjam dalam kehidupan masyarakat nusantara adalah suatu hal yang biasa/lazim, baik dilakukan antarsaudara atau tetangga. Semangat yang menjadi asas adalah semata-mata tolong menolong, sehingga sama sekali tidak dikenakan bunga atau tambahan terhadap bayaran balik terhadap pinjaman.

Pinjaman model ini biasanya berlaku di antara orang dengan orang yang sudah kenal baik, karena dasarnya adalah rasa saling percaya. Rasa saling percaya itu timbul di antara orang yang memang sudah kenal baik. Kalau orang yang dipinjami ițu percaya dengan orang yang meminjam, maka diberilah peminjam itu, jika tidak percaya terhadap peminjam, maka terkadang- dengan alasan tertentu (yang dibuat-buat), pinjaman tidak diberikan kepada peminjam.

Pada umumnya, tidak mudah seseorang pinjam kepada orang lain, karena orang tersebut sangat menjaga kewibawaan. la baru akan meminjam'bila betul-betul sudah tidak ada jalan lain. Pinjaman itu biasanya berupa uang atau barang yang untuk keperluan konsumsi, bukan untukberdagang atau keperluan bisnis. Mereka tidak meminjam ke bank atau institusi lain karena selain sebagian mereka tidak tahu prosedur pinjam di bank, juga mereka takut dengan bunga yang dikenakan bank.

Apabila pinjaman itu untuk keperluan bisnis, ketika mengembalikan pinjaman biasanya si peminjam memberikan tambahan terhadap pokok pinjaman dengan mengikut budi baiknya. Yang perlu dicatat di sini, bahwa tambahan terhadap pokok pinjaman itu tidak dipersyaratkan dan tidak ditentukan jumlahnya ketika akad pinjam - meminjam terjadi. Praktik semacam ini sering terjadi di masyarakat Jawa, bahkan hingga kini masih dipraktikkan oleh sebagian orang.

\section{4). Bai'as-Salam}

Model jual beli semacam ini seringkali dipraktikkan oleh masyarakat nusantara dalam hal membeli barang rumah tangga, misal meja kursi, almari, bufet dan lain-lain. Si pembeli biasanya mendatangi tempat penjual dengan sekaligus memberikan uang sejumlah harga barang yang dipesan, untuk kemudian jika barang yang dipesan sudah jadi kemudian diantar oleh penjual ke pembeli. Praktik semacam ini, masih diamalkan hingga saat ini oleh masyarakat desa di Jawa. 


\section{4). ljarah}

Prinsip ini biasa dipraktikkan dalam sewa lahan berupa sawah atau kebun. Ketika akad terjadi, jangka waktu sewa telah ditentukan termasuk harga sewanya. Pembayaran dilakukan dengan tunai. Akad semisal juga biasa dilakukan untuk sewajasa misalnya sewa mobil atau peralatan tertentu yang si penyewa bisa mendapatkan manfaat dari barang tersebut. Amalan sejenis ini juga masih diamalkan hingga saatini.

\section{5). Bay'al-Urbun}

Pembelian suatu barang dengan down payment (DP)/uang muka sebagai tanda jadi yang notabenenya berbasis akad bay'al-urbun dalam fiqh muamalah, banyak dipaktikkan dalampembelian rumah, mobil, motor, dan lain-lain. Dalam praktiknya, kemudian dilkuti dengan akad yang lain, misalnya bay' bi thaman ajil / bay' almurabahah. Memang tidak semua praktik down payment (DP)/uang muka sebagai tanda jadi yang berbasis pada akad bay' al-urbun sesuai dengan Syariah, karena terkadang masih menimbulkan kezaliman pada suatu pihak, akan tetapi secara faktual itu dapat dinyatakan sebagai bagiann dari praktik akad bay' al-urbun dalam kehidupan masyarakatmuslim Indonesia.

\section{Masa Depan Aktivitas Ekonomi Berbasiskan Ekonomi Islam}

Perkembangan praktik ekonomi Islam dalam berbagai bidangnya pada sepuluh tahun terakhir menunjukkan pertumbuhan yang sangat impresif. Kalau dulu belum ada dukungan yang nyata dari pemerintah, dalam sepuluh tahun terakhir, dukungan pemerintah sangat kentara, antara lain: diundangkannya UU Nomor 19 tahun 2008 tentang Surat Berharga Syariah Negara (SBSN): Lahirnya UU SBSN memberikan harapan di tengah APBN yang selalu defisit untuk bisa mendorong tersedianya sumber keuangan alternatif bagi negara. UU SBSN saatini telah menjadi landasan hukum bagi pemerintah Rl untuk penerbitan sukuk negara guna menarik dana dari investor. Sukuk dipandang sebagai alternatif yang lebih baik daripada berutang ke luar negeri karena antara lain mengandung unsur kerja sama investasi; berbagi resiko dan keterlibatan aset (proyek riil) yang juga mendasari penerbitan sukuk (Musari, 2009).

Pada tahun yang sama diundangkan pula UU No. 21-Tahun 2008 tentang Perbankan Syariah. Lahirnya UU Perbankan Syariah menandai era baru perbankan Syariah berpayung hukum jelas. Dengan UU Perbankan Syariah ini makin memperkuat landasan hukum perbankan Syariah sehingga dapat setara-dengan bank konvensional. Selain itu, payung hukum ini makin menguatkan eksistensi perbankan syariah di Indonesia dan juga dapat makin memacu peningkatan peran dan kontribusi perbankan syariah dalam mengentaskan kemiskinan (poverty alleviation), kesejahteraan masyarakat, dan pembukaan lapangan kerja serta pembangunan nasional.

Dukungan nyata pemerintah RI yang lain adalah didirikannya Bank Syariah oleh BUMN, yaitu berdirinya Bank Syariah Mandiri (BSM) yang modal inti terbesarnya dari Bank Mandiri yang nota bene merupakan bank BUMN, berdirinya BRI Syariah yang modal inti terbesarnya dari Bank BRI yang nota bene merupakan bank BUMN, BNI Syariah yang modal inti terbesarnya dari BNI 46 yang nota bene juga bank BUMN, Pegadaian Syariah yang berada di bawah perum pegadaian yang merupakan BUMN, dan lain-lain.

Dalam ranah keuangan publik, diundangkan UU No. 41 Tahun 2004 tentang Wakaf. Untuk melengkapi Undang-undang tersebut, pemerintah juga telah menetapkan Peraturan Pemerintah Nomor 42 tahun 2006 tentang Pelaksanaan Undang-undang Nomor 41 tahun 2004, ditambah Kepmen Nomor 04 Tahun 2009 tentang Administrasi Wakaf Uang.

Sebelum itu telah diundangkan UU No. 38 Tahun 1999 tentang Zakat. Diundangkannya UU Zakat menunjukkan politik ekonomi Islam dalam ranah keuangan publik pemerintah RI cukup akomodatif terhadap 
kebutuhan umat Islam untuk melaksanakan rukun Islam yang ke-3. Menurut Direktorat Pemberdayaan Zakat, potensi zakat yang dapat dikumpulkan secara nasional mencapai 39 triliun Rupiah per tahun. Angka ini hampir sama dengan hasil kajian Rumah Zakat.

Disisi lain, sebagai pengawal hukum Syariah dalam praktik lembaga keuangan dan bisnis yang berbasis Syariah, telah didirikan Dewan Syariah Nasional Majelis Ulama Indonesia (DSNMUI). MUI sebagai lembaga yang memiliki kewenangan dalam bidang keagamaan yang berhubungan dengan kepentingan umat Islam Indonesia membentuk suatu dewan syariah yang berskala nasional yang bernama Dewan Syariah Nasional (DSN), berdiri pada tanggal 10 Februari 1999 sesuai dengan Surat Keputusan (SK)-MUI No. kep-754/MUI/I/1999. Lembaga DSN MUI ini merupakan lembaga yang memiliki otoritas kuat dalam penentuan dan penjagaan penerapan prinsip Syariah dalam operasional di lembaga keuangan Syariah, baik perbankan Syariah, asuransi Syariah dan lain-lain. Hal ini sebagaimana termuat dalam UU No.21 Tahun 2008 tentang Perbankan Syariah pasal 32 maupun UU No.40 Th 2007 tentang Perseroan Terbatas pasal 109 yang pada intinya bahwa Dewan Pengawas Syariah wajib dibentuk di bank Syariah maupun perseroan yang menjalankan kegiatan usaha berdasarkan prinsip syariah. Dewan Pengawas Syariah tersebut hanya dapat diangkatjika telah mendapatkan rekomendasi DSN MUI.

Dalam hal hukum materiil, telah disusun KHES (Kompilasi Hukum Ekonomi Syari'ah). Penyusunan Kompilasi Hukum Ekonomi Syari'ah (KHES) yang dikordinir oleh Mahkamah Agung (MA) Rl yang kemudian dilegalkan dalam bentuk PERATURAN MAHKAMAH AGUNG (PERMA) 02 Tahun 2008 merupakan respon terhadap perkembangan baru dalam kajian dan praktek ekoriomi Islam di Indonesia. Kehadiran KHES merupakan. bagian upaya positivisasi hukum perdata Islam dalam sistem hukum nasional. Untuk saat ini positivisasi hukum ekonomi Islam sudah menjadi keniscayaan bagi umat Islam, mengingat praktik ekonomi syari'ah sudah semakin semarak melalui LKS-LKS. Kompilasi tersebut kemudian dijadikan acuan dalam penyelesaian perkara-perkara ekonomi syari'ah yang semakin hari semakin bertambah, seiring dengan perkembangan LKS. Adapun lembaga peradilan yang berkompetensi dalam penerapan KHES adalah Peradilan Agama (PA) sebagaimana diamanatkan UUNo. 3 Tahun 2006.

Berdasarkan deskripsi di atas, perkembangan dan pertumbuhan praktik ekonomi Islam di Indonesia dapat dikatakan sangat pesat, apalagi setelah mendapat dukungan pemerintah. Realitas yang demikian, memberikan harapan besar yang menumbuhkan optimisme bagi umat Islam untuk terus berupaya mengembangkan ekonomi Islam di Indonesia, terlebih lagi dukungan pemerintah yang diwujudkan dalam berbagai regulasi dan political will semakin nyata mendukung pengembangan ekonomi Islam di Indonesia. Dengan demikian dapat dinyatakan bahwa masa depan praktik ekonomi Islam di Indonesia sangat menjanjikan.

\section{Kesimpulan}

Islam yang berkembang di Indonesia mempunyai tipikal yang spesifik bila dibandingkan dengan ajaran Islam di berbagai negara muslim lainnya. Islam di Indonesia adalah Islam yang akomodatif dan cenderung elastis dalam berkompromi dengan situasi dari kondisi yang berkembang di Indonesia. Dialog dan dialektika antara Islam dan budaya lokal nusantara melahirkan wajah Islam yang khas Indonesia, sehingga dikenal sebagai Islam Nusantara.

. Dialog dan dialektika antara Islam dan budaya lokal dalam bidang ekonomi sebagai wujud dari bagian tampilnya wajah Islam nusantara terlihat dalam berbagai ragam aktivitas ekonomi umat Islam di nusantara (Indonesia) yang merupakan bentuk kearifan lokal berwajah Islam nusantara dalam rangka menampilkan karakter Islam yảng salihun likulli zaman wa li kulli makan. Di antara aktivitas ekonomi umat Islam di nusantara (Indonesia) itu antara lain: penolakan terhadap riba yang dianggap sebagai lintah darat, diterapkannya berbagai pola bagi hasil yang disebut dengan bawon, maro/paro, mrotelu, gaduh, garap, marnen, dan lain-lain. Bahkan dalam konteks bisnis modern, pola bagi hasil juga diterapkan, di antaranya franchise, dan lain-lain. 
Berdasarkan deskripsi di atas, perkembangan dan pertumbuhan praktik ekonomi Islam di Indonesia dapat dikatakan sangat pesat belakangan ini, terutama setelah mendapat dukungan pemerintah dalam bentuk politik ekonomi yang berlandaskan pada prinsip-prinsip ekonomi Islam. Perkembangan pesat tersebut dapat terlihat dalam bèrbagai bidang ekonomi yang menerapkan sistem ekonomi lslam, seperti perbankan Syariah, asuransi Syariah, sukuk, pasar modal Syariah, keuangan publik, dan lain-lain. Kenyataan ini, menumbuhkan harapan dan optimisme bagi umat Islam untuk terus berupaya mengembangkan ekonomi Islam dan mengamalkannya dalam praktik berekonomi di Indonesia, sehingga nantinya ekonomi Islam betul-betul menjadi salah satu wujud khas Islam nusantara dalam aktivitas ekonomi.

\section{Daftar Pustaka}

Ahmad, Amrullah dkk (Ed.). (1996). Dimensi Hukum Islam dalam Sistem Hukum Nasional: Mengenang 65 Th Prof.Dr.H. Busthanul Arifin SH. Jakarta: Gema Insani Press.

Al-Ghazali (t.t.). al-Mustasfa. Beirut: Dar al-Fikr.

DEPAGRI,Al-Quran dan Terjemahnya.

Al-Syaukani (tanpa tahun). Irsyad al-Fuhulila Tahqiq al-Haq min 'IIm al-Usul. Beirut: Dar al-Fikr.

Anis, lbrahim et al.(tanpa tahun). al-Mu'jam al-Wasit, juz. 1. Kairo:T.P.

Antonio, Muhammad Syafii (2001). Bank Islam dari Teori ke Praktek. Jakarta: Gema Insani Press.

Asy-Syatibi (tanpa tahun). al-Muwafaqatfi Usul al-Ahkam, juz Il. Beirut: Dar al-Fikr.

Auni bin HajiAbdullah (2001). Islam dan Perdagangan dalam Sejarah Alam Melayu. Kuala Lumpur: Darulfikir Sdn Bhd.

Basyir, Ahmad Azhar (1999). "Hukum Islam ḍi Indonesia dari Masa ke Masa", dalam Peradilan Agama dan Kompilasi Hukum Islamdalam Tata Hukum Indonesia, Edisi Il. Yogyakarta:UII Press.

Djamil, Fathurrahman (1995). Metode litihad Majlis Tariih Muhammadiyah. Jakarta: Logos Publishing House. DEPAG RI, (2006). Peraturan Perundangan Penwakafan. Jakarta: DEPAGRI.

Ghani, Ab. Mumin Ab. (1999). Sistem Kewạngan Islam dan Pelaksanaannya di Malaysia. Kuala Lumpur: Jabatan Kemajuan Islam Malaysia.

Harun Nasution, (1988). "Jjtihad Sumber Ketiga Ajaran Islam", dalam Haidar Baqir, ljtihad dalam Sorotan. Bandung: Mizan.

Ibn'Abidin (1966). Hasyiyah Ibn 'Abidin, juz5. Kairo

Iqbal (1981). The Reconstruction of Religious Thought in Islam. India: Kitab Bhavan.

Jammal, Muhammad 'Abd al-Mun'im al- (1986). Mawsu'ah al-Iqtisad al-Islami wa Dirasah Muqaranah, cet. 2. Beirut: Dar al-Kutub al-Lubnani.

Jasas, Al-ImamAbu BakrAhmad Bin'Alial-Razial-(f.t). Ahkam al-Qur'an, juz. 2. Kairo: Matba'ah al-Bahiyyah Jusmaliani, (2006). Aktivitas EkonomiBerbasisBagi Hasil. Jakartạ: P2E LIPI.

Mannan, Muhammad Abdul, (1986). Islamic Economics: Theory and Practice (Foundation of /slamic Economics). Cambridge: The Islamic Academy.

Maududi, Abu al-'Ala al-(1987). al-Riba. Jeddah: al-Dar al-Su'udiyyah. 
Misri, 'Abd al-Sami' al-(1987). Limadha HarramaAllah al-Riba?. Kairo: Maktabah Wahbah.

(1999). Fa'idah al-Qard wa Nazariyyatuha al-Hadithah (Min Wijhati Nazri al-Islam), Beirut: Dar al-Fikr al-Mu'asir. (1999). Usul al-Iqtisad al-Islami. Beirut: al-Dar al-Syamiyyah.

Muhaimin, Yahya A. (1992). "Budaya Politik dan Pembangunan Hukum Nasional", dalam Politik Pemibangunan Hukum Nasional. Yogyakarta: UII Press.

Muhammad (2002). Manajemen Bank Syariah. Yogyakarta:UMPYKPN.

Nadwi, 'AliAhmad al-(1999). Mausu'ah al-Qawa'id wa al-Dawabital-Fighiyyah. Beirut:Dar'Alamal-Ma'rifah.

Nasution, Harun (1985). "Dasar Pemikiran Pembaharuan dalam Islam", dalam M. Yunan Yusuf, et al (Ed.). Cita dan Citra Muhammadiyah. Jakarta: Pustaka Panjimas.

Poesponegoro, M.D. dan Noegroho Notosusanto (1984). Sejarah Nasional Indonesia, jilid III. Jakarta: Balai Pustaka.

PPIKAHA(1996). "Kata Pengantar" dalam Dimensi Hukum Islam dalam Sistem Hukum Nasional. Jakarta: GIP

Qaradawi Yusuf al-(1994). al-litihad al-Mu,asir, Dar at-Tauzi' wa an-Nasy al-Isiamiyah.

(1999). Fawa'id al-Bunuk hiya al-Riba al-Haram. Kairo:Maktabah Wahbah.

(t.t). Madkhal lidirasah asy Syari'ah al-Islamiyah. Kairo:Maktabah Wahbah.

Qayyim, Ibnual-(1977). I'lam al-Muwaqqi'n'an Rabbal-'Alamin (cet. Ke-2, juz III). Beirut: Daral-Fikr.

Qudamah, 'Abdullah Ibn Ahmad al-Maqdisi Ibn, (1972). Al-Mughni wa al-Syarh al-Kabir(3il. 4). Beirut: Daral-Kutub al-'Arabi.

Qureshi,Anwar Iqbal, (1961). Islam and The Theory of Interes, (ed. 2). Lahore: SH Muhammad Ashraf

Rahman, Afzalur (1980). Economic Doctrines of Islam (ed. 2, Vol.3). Lahore: Islamic Publication Limited.

Rifki lsmal \& Khairunnisa Musari, "Menggagas Sukuk sebagai Instrumen Fiskal dan Moneter", Bisnis Indonèsia edisi 1 April 2009.

Saeed,Abdullah (1996). Islamic Banking and Interest. Leiden: E.J Brill.

Saleh, Nabil A. (1986). Unlawful Gain and Legitimate Profit in Islamic Law. Cambridge: Cambridge University Press.

Tabari, 'Imad al-Din bin Muhammad al-(1985). Ahkam al-Qur'an, juz. 3. Beirut: Dar al-Kutub ạl-'Ilmiyyah.

Taher, Sayyid, (1997). "Riba-Free Alternatives for A Modern Economy", dalam Masudul Alam Choudhury, Islamic Political Economy in Captapist-GlobalizationAnAgenda for Change. Kuala Lumpur: Utusan Publications \& Distributors Sdn. Bhd.

Umi Karomah (ed.) (2010). Usaha Bagi Hasil. Yogyakarta: Kreasi Wacana.

Yusdani (2000). Peranan Kepentingan Umum dalam Reaktualisasi Hukum: Kajian Konsep Hukum Islam Najamuddin at-Tufi. Yogyakarta: UIIPress. 